\title{
ALTERNATIF KEBIJAKAN DALAM MENGATASI PERILAKU DIGITAL DI INDONESIA
}

\section{POLICY ALTERNATIVES IN OVERCOMING DIGITAL BEHAVIOR IN INDONESIA}

\begin{tabular}{|c|c|}
\hline $\begin{array}{l}\text { Adang Aldhila }{ }^{1} \\
\text { Universitas } \\
\text { Diponegoro } \\
\text { Semarang, Indonesia }{ }^{1} \\
\text { email: } \\
\text { adangaldhila@gmail. } \\
\text { com } \\
\text { Augustin Rina } \\
\text { Herawati } \\
\text { Universitas } \\
\text { Diponegoro } \\
\text { Semarang, Indonesia }{ }^{2} \\
\text { Kismartini }{ }^{3} \\
\text { Universitas } \\
\text { Diponegoro }_{\text {Semarang, Indonesia }}\end{array}$ & 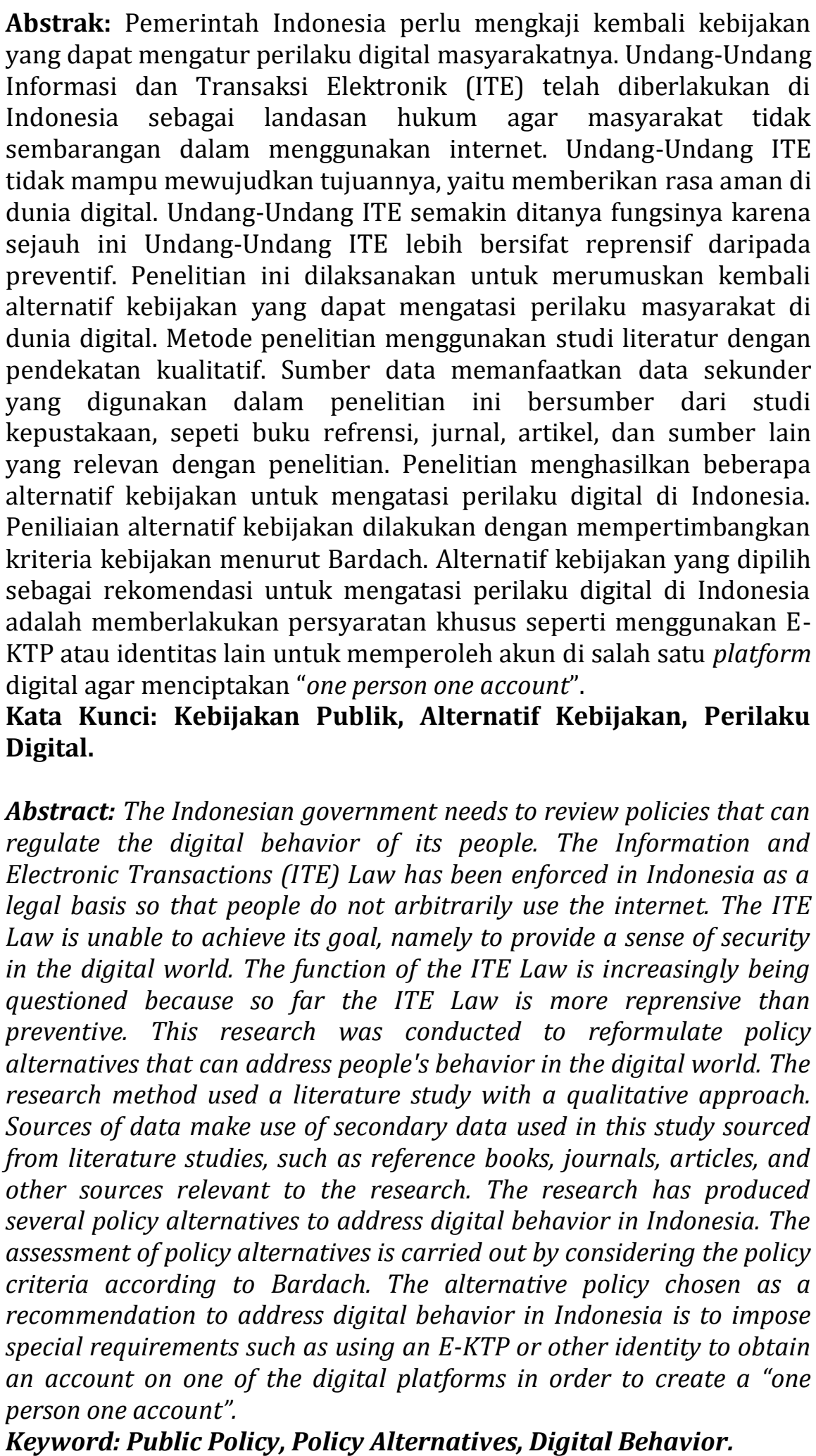 \\
\hline
\end{tabular}




\section{PENDAHULUAN}

Sejalan dengan perkembangan zaman, globalisasi menjadi sesuatu yang tidak dapat dihindari bagi setiap negara. Negara maju maupun negara berkembang harus dapat beradaptasi dengan globalisasi agar tidak menjadi negara yang tertinggal dalam persaingan Internasional. Indonesia sebagai negara yang berkembang harus dapat menjadikan globalisasi sebagai peluang untuk menuju negara maju. Globalisasi dalam negara berkembang tentu memiliki berbagai macam dampak baik dan dampak buruk. Negara harus bijak dalam menyaring dampak dari globalisasi, jangan sampai suatu negara kehilangan identitasnya karena globalisasi. Bentuk adaptasi akan globalisasi pada dasarnya adalah dengan mampu memanfaatkan teknologi.

Teknologi muncul untuk memudahkan manusia mengakses informasi dan memudahkan manusia dalam berkomunikasi. Rusman (2012) mengemukakan bahwa teknologi adalah suatu alat yang berguna untuk mempermudah aktivitas manusia. Perkembangan Ilmu Pengetahuan dan Teknologi (IPTEK) di Indonesia memunculkan istilah Teknologi Informasi dan Komunikasi (TIK). Sutrisno (2011) mengemukakan pengertian Teknologi Informasi (TIK) adalah semua teknologi yang behubungan pengambilan, pengumpulan (akuisisi), pengolahan, penyimpanan, penyebaran, dan penyajian informasi. Keberhasilan negara dalam penggunaan Teknologi Informasi dan Komunikasi dapat dilihat dari Indeks Pembangunan Teknologi Informasi dan Komunisasi (IP-TIK). International Telecommunication Union (ITU) pada tahun 2017 merilis hasil survei mengenai Indeks Pembangunan Teknologi Informasi dan Komunisasi (IP-TIK). Indonesia memperoleh score IP-TIK sebesar 4,33 dan berada pada nomor urut 111 dari 175 negara yang disurvei (BPS, 2020). Apabila dibandingkan dengan negara di ASEAN, Indonesia hanya unggul dari Timor Leste, Kamboja, Myanmar, dan Laos (Vernanda, 2019). Peringkat Indonesia dalam IP-TIK yang cukup tertinggal dari negara-negara lain menandakan bahwa Indonesia masih perlu berbenah dalam memanfaatkan teknologi informasi dan komunikasi.

Pemanfaatan teknologi informasi dan komunikasi menjadikan Indonesia menuju negara yang digital. Digitalisasi di Indonesia melaju pesat dan berkembang semakin luas. Setiap warga negara di Indonesia sudah semakin terbiasa dalam mengunakan teknologi digital. Perkembangan digitalisasi di masyarakat tentunya memiliki berbagai macam manfaat seperti memudahkan masyarakat dalam berkomunikasi dengan keluarga, teman, dan kolega tanpa harus mempertimbangkan jarak. Wujud nyata yang 
paling tampak manfaat dari digitalisasi di Indonesia adalah pada masa pandemi Covid19, dimana segala aktivitas yang dahulunya hanya bisa dilakukan dengan bertemu langsung sekarang dapat dilakukan secara digital (online). Namun, selain manfaat yang diterima tentunya ada dampak negatif yang sangat sulit dihindari dari berkembangnya digitalisasi di masyarakat luas.

Regulasi untuk membatasi dan menyaring globalisasi informasi dibuat oleh pemerintah Indonesia melalui "Undang-Undang Nomor 19 Tahun 2016 Tentang Perubahan Atas Undang-Undang Nomor 11 Tahun 2008 Tentang Informasi dan Transaksi Elektronik". Dewasa ini UU ITE masih belum optimal dalam membuat masyarakat Indonesia bijak di dunia digital. Hal tersebut tentunya dikarenakan jumlah penduduk di Indonesia yang tergolong banyak dan terus mengalami peningkatan. Penduduk Indonesia pada tahun 2010 sebesar 237,6 Juta jiwa meningkat pada tahun 2020 menjadi 270,2 juta jiwa (BPS, 2021).

Permasalahan kesopanan masyarakat di dunia digital merupakan bentuk kurang matangnya pemerintah dalam mengatur dan membatasi masyarakat di dunia digital. Microsoft melakukan survei tentang tingkat kesopanan digital (Digital Civility Index/DCI) dan menempatkan Indonesia menjadi negara paling tidak sopan di AsiaPasifik.

\section{Gambar 1. Indeks Kesopanan Digital di Asia-Pasifik}

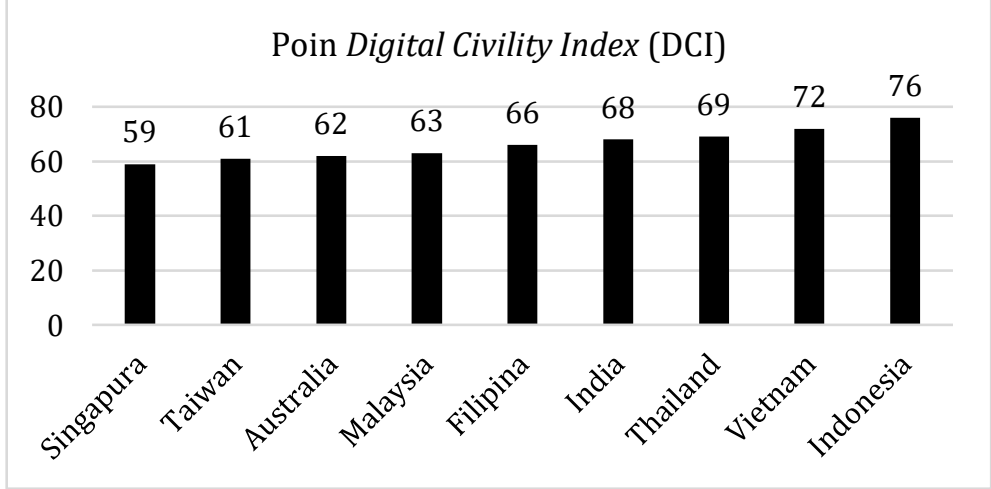

Sumber: Microsoft.com, Februari 2021

Berdasarkan diagram diatas dapat dilihat score DCI yang diperoleh oleh Indonesia adalah 76 poin dimana jika score DCI makin mendekati 100 maka tingkat kesopanan masyarakat dalam dunia digital semakin buruk. Pada tahun 2019 angka tingkat kesopanan digital masyarakat Indonesia sebesar 68 poin dan meningkat sebanyak 8 poin ditahun 2020. Artinya pada tahun 2020 Indonesia semakin berperilaku tidak sopan 
daripada tahun sebelumnya. Adapun yang mempengaruhi angka tingkat kesopanan digital Indonesia.

\section{Gambar 2. Risiko Kesopanan Digital di Indonesia}

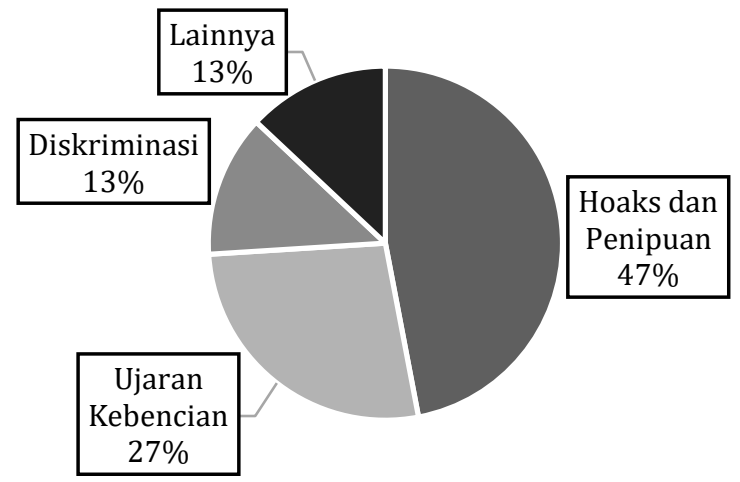

Sumber: Microsoft.com, 2021

Berdasarkan diagram diatas, tingkat kesopanan digital di Indonesia paling besar di dominasi karena hoaks dan penipuan (47\%), kemudian disusul oleh ujaran kebencian (27\%), Diskriminasi (13\%) dan lainnya (13\%). Data menjelaskan bahwa penyebaran berita hoaks dan penipuan sering terjadi pada tahun 2020 di Indonesia. Ujaran kebencian masih sering terjadi di Indonesia pada tahun 2020. Salah satu bentuk ujaran kebencian adalah persiakan (bullying). Survei Microsoft tentang kasus persiakan (bullying) di dunia digital Indonesia sejalan dengan dampak karena tingkat kesopanan digital Indonesia yang buruk. Survei dilakukan dengan membagi masyarakat yang terkena kasus persiakan (bullying) di dunia digital berdasarkan generasi-generasi di masyarakat.

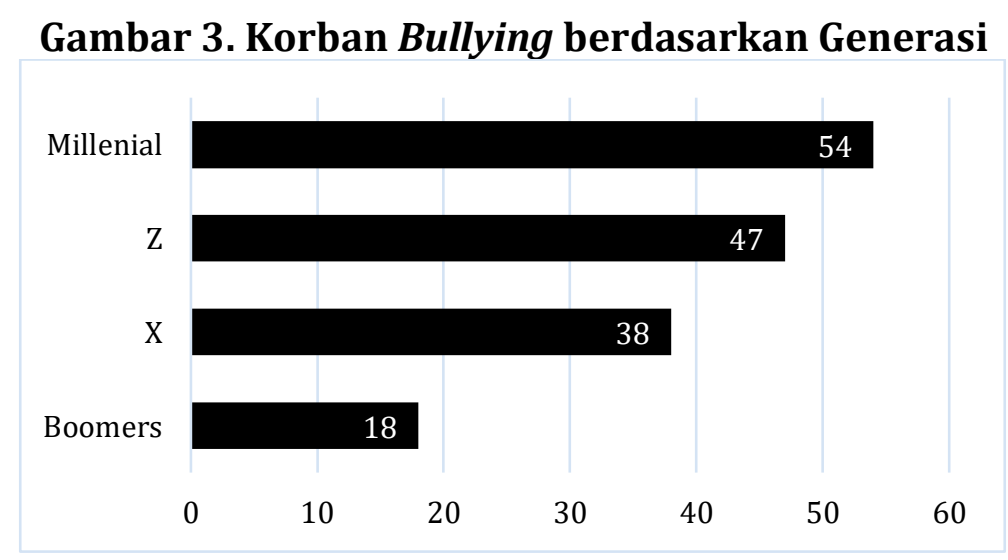

Sumber: Microsoft, Februari 2021

Berdasarkan diagram tersebut, generasi yang paling banyak menjadi korban persiakan (bullying) adalah generasi millennial, dilanjutkan oleh generasi Z, X, dan 
Boomers. Indonesia saat ini didominiasi oleh generasi Z (27,94\%), yaitu generasi yang lahir 1997 sampai 2012. Kemudian disusul dengan generasi millenial (25,87\%), yaitu generasi yang lahir tahun 1981-1996 (BPS, 2021). Generasi milenial dan generasi Z merupakan generasi yang berusia produktif di Indonesia sehingga perlu sekali menjadi pusat perhatian pemerintah Indonesia. Sebagai penduduk yang memiliki usia produktif tentu kasus persiakan (bullying) yang sering diterima dikhawatirkan dapat mengganggu kesehatan mental dan mempengaruhi produktivitas dari generasi ini.

Pemerintah Indonesia perlu mengkaji kembali kebijakan yang dapat mengatur perilaku digital masyarakatnya. Natoatmodjo (2003), "perilaku adalah suatu kegiatan dan aktifitas organisme yang bersangkutan, baik aktifitas yang dapat diamati atau aktifitas yang tidak dapat diamati oleh orang lain". Undang-Undang ITE telah diberlakukan di Indonesia sebagai landasan hukum agar masyarakat tidak sembarangan dalam menggunakan internet. Segala ketentuan, larangan serta hukuman sudah diatur dalam regulasi ini. Semenjak Undang-Undang ITE terakhir kali disempurnakan tahun 2016, data survei menunjukkan bahwa masyarakat (netizen) Indonesia semakin buruk dalam perilaku di dunia digital. Undang-Undang ITE tidak mampu mewujudkan tujuannya, yaitu memberikan rasa aman di dunia digital. UndangUndang ITE semakin ditanya fungsinya karena sejauh ini Undang-Undang ITE lebih bersifat reprensif daripada preventif. Untuk itu perlu dianalisis kembali kebijakan yang telah dibuat dan merumuskan alternatif kebijakan yang dapat mengatasi perilaku masyarakat di dunia digital. Alternatif kebijakan harus cukup efektif dan efisien untuk mencegah masyarakat melakukan pelanggaran di dunia digital.

\section{METODE}

Desain penelitian menggunakan pendekatan kualitatif dan studi literatur sebagai metode penelitiannya. Nazir (2014) mengemukakan metode penelitian studi literatur merupakan metode dengan menelaah secara tekun akan kepustakaan yang berhubungan akan penelitian. Pendekatan kualitatif berlandaskan filsafat post positivisme yang digunakan untuk meneliti objek secara ilmiah (Sugiyono, 2018). Penelitian ini menggunakan data sekunder untuk menganalisis dan menjawab pertanyaan penelitian. Sugiyono (2012) menjelaskan data sekunder adalah data yang bersumber dari hasil pengolahan lebih lanjut dari data primer yang disajikan dalam bentuk lain atau dari orang lain. Data Sekunder yang digunakan dalam penelitian ini 
bersumber dari studi kepustakaan, sepeti buku refrensi, jurnal, artikel, dan sumber lain yang relevan dengan penelitian.

\section{HASIL DAN DISKUSI}

\section{Tujuan Analisis Kebijakan}

Kebijakan sangat diperlukan dalam memecahkan suatu permasalahan atau persoalan yang ada. Nugroho (2009) mengemukakan "kebijakan merupakan arah tindakan yang mempunyai maksud yang ditetapkan oleh seorang aktor atau sejumlah aktor dalam mengatasi suatu permasalahan atau persoalan". Dye (Suharto 2005), “Kebijakan publik adalah apapun yang dipilih oleh pemerintah untuk dilakukan atau tidak dilakukan. Pemerintah Indonesia telah mengeluarkan kebijakan untuk mengatur kegiatan di dunia elektronik melalui “Undang-Undang Nomor 19 Tahun 2016 Tentang Perubahan Atas Undang-Undang Nomor 11 Tahun 2008 Tentang Informasi dan Transaksi Elektronik" yang bertujuan untuk memberikan rasa aman, keadilan, dan kepastian hukum bagi pengguna dan penyelenggara teknologi informasi.

Hingga saat ini tujuan kebijakan tersebut belum tercapai secara optimal. Tujuan tersebut tidak tercapai karena indeks kesopanan digital Indonesia masih tergolong buruk, bahkan paling buruk di Asia-Pasifik. Masih banyaknya hoaks dan penipuan, ujaran kebencian, diskriminasi, hingga bullying yang tinggi sebagai penyebab angka kesopanan digital Indonesia buruk. Oleh karena itu perlu di analisis kembali kebijakan yang telah diberlakukan di Indonesia. Dunn (Meutia 2017), “analisis kebijakan publik adalah suatu disiplin ilmu sosial, terapan, yang menggunakan berbagai macam metodologi penelitian dan argumen untuk menghasilkan dan mentransformasikan informasi yang relevan dengan kebijakan yang digunakan dalam lingkungan politik tertentu untuk memecahkan masalah-masalah kebijakan". Setelah melakukan analisis kebijakan publik maka dapat merumuskan alternatif kebijakan yang sesuai.

Tabel 1. Tujuan Analisis Kebijakan

\begin{tabular}{|c|c|c|}
\hline NO & Formulasi Masalah & Tujuan Kebijakan \\
\hline 1 & $\begin{array}{l}\text { Tingginya indeks kesopanan digital di } \\
\text { Indonesia yang berarti tingkat kesopanan } \\
\text { digital Indonesia sangat buruk. }\end{array}$ & $\begin{array}{l}\text { Untuk mengurangi angka indeks } \\
\text { kesopanan digital di Indonesia atau } \\
\text { menciptakan masyarakat yang sopan } \\
\text { dalam dunia digital. }\end{array}$ \\
\hline 2 & $\begin{array}{l}\text { Masih banyaknya terjadi penyebaran berita } \\
\text { hoaks dan penipuan, ujaran kebencian, } \\
\text { diskriminasi, dan perilaku buruk lainnya di } \\
\text { dunia digital. }\end{array}$ & $\begin{array}{l}\text { Mengurangi terjadi penyebaran berita } \\
\text { hoaks dan penipuan, ujaran kebencian, } \\
\text { diskriminasi, dan perilaku buruk lainnya } \\
\text { di dunia digital. }\end{array}$ \\
\hline 3 & Masih sering terjadinya persiakan (bullying) & mengurangi \\
\hline
\end{tabular}




\begin{tabular}{|c|c|c|}
\hline & $\begin{array}{l}\text { yang didominasi oleh generasi millenial dan } \\
\text { generasi Z sebagai korbannya. }\end{array}$ & $\begin{array}{l}\text { (bullying) terutama terhadap generasi } \\
\text { millenial dan generasi Z. }\end{array}$ \\
\hline 4 & $\begin{array}{l}\text { Masyarakat sulit mendapatkan rasa aman } \\
\text { dan nyaman di dalam dunia digital terutama } \\
\text { dalam bersosial media. }\end{array}$ & $\begin{array}{l}\text { Menciptakan rasa aman dan nyaman di } \\
\text { masyarakat dalam dunia digital terutama } \\
\text { dalam bersosial media. }\end{array}$ \\
\hline
\end{tabular}

Sumber: Diolah Penulis, 2021

\section{Kriteria Kebijakan}

Kriteria kebijakan sangat diperlukan dalam menganalisis suatu kebijakan dan menyusun alternatif kebijakan. Penentuan kriteria kebijakan yang tepat akan mampu menciptakan alternatif kebijakan yang tepat pula untuk menyelesaikan permasalahan yang ada. Khairi (2014), penentuan kriteria kebijakan menjadi proses yang dilakukan dengan mencakup informasi-informasi yang dinilai secara mendalam dan detail yang relevan dengan masalah-masalah yang sedang dihadapi. Brigman dan Davis (Mualim \& Kismartini, 2008) menjelaskan bahwa parameter kebijakan perlu untuk diidentifikasikan dalam proses analisis kebijakan publik sebagai suatu pengujian terhadap hal-hal yang mungkin dilakukan berkaitan dengan sebuah proposal kebijakan.

Perumusan alternatif kebijakan untuk mengatasi perilaku digital di Indonesia tentu harus menentukan terlebih dahulu kriteria kebijakan yang berhubungan dengan hal ini. Bardach (2012) mengemukakan ada 4 pertimbangan dalam menentukan kriteria kebijakan, yaitu "Technical Feasibility (Kelayakan Teknis), Economic and Financial possibility (Kemungkinan Ekonomi dan Finansial), Political Viability (Kehidupan Politik), dan Administrative operability (Pengoprasian Administrasi)". Selanjutnya kriteria kebijakan dioperasionalisasikan lebih detail untuk mengatasi perilaku digital.

\section{Tabel 2. Operasionalisasi Kriteria}

\begin{tabular}{|c|c|c|}
\hline No & Aspek Kriteria & Kriteria Mengatasi Perilaku Digital di Indonesia \\
\hline 1 & Kelayakan Teknis & $\begin{array}{l}\text { - Mengawasi masyarakat dengan intens dalam } \\
\text { menggunakan internet atau sosial media. } \\
\text { - Mencegah masyarakat berperilaku buruk di dunia } \\
\text { digital. } \\
\text { - Meningkatkan kesopanan digital masyarakat dan bijak } \\
\text { dalam menggunakan internet atau sosial media. }\end{array}$ \\
\hline 2 & Ekonomi/Finansial & - Menggunakan biaya/anggaran dengan efisien \\
\hline 3 & Kehidupan Politik & $\begin{array}{l}\text { - Tidak mendapatkan penolakan dari berbagai } \\
\text { stakeholder yang terlibat. } \\
\text { - Tersalurnya kepentingan stakeholder yang terlibat. }\end{array}$ \\
\hline 4 & Pengoprasian Administrasi & $\begin{array}{l}\text { - } \quad \text { Pelaksanaan dapat terorganisir dengan baik. } \\
\text { - Akuntabilitas terhadap seluruh stakeholder. }\end{array}$ \\
\hline
\end{tabular}

Sumber: Diolah Penulis, 2021 


\section{Alternatif Kebijakan}

Setelah kriteria kebijakan ditentukan, maka selanjutnya adalah menentukan alternatif kebijakan untuk mengatasi suatu permasalahan. Khairi (2014) mengemukan ada lima metode dalam menentukan alternatif kebijakan, yaitu "researched analysis and experimentation, no-actions analysis, quick surveys, literature review, dan comparison of real world experience". Alternatif-alternatif kebijakan disusun dengan mempertimbangkan kriteria-kriteria kebijakan. Alternatif kebijakan yang ditawarkan dalam mengatasai perilaku digital di Indonesia, yaitu (1) bekerjasama dengan perusahaan media sosial dalam hal mengawasi kegiatan masyarakat di sektor digital, (2) memberlakukan persyaratan khusus seperti menggunakan E-KTP atau identitas lain untuk memperoleh akun di salah satu platform digital agar menciptakan "one person one account", (3) mendirikan lembaga khusus untuk perizinan dan pengawasan bagi pengguna dan pihak pengelola Media Sosial, (4) aktif melakukan sosialisasi dan himbauan bijak bersosial media di berbagai platform media sosial, terutama platform yang paling sering diakses oleh generasi $\mathrm{Z}$ dan milenial.

\section{Penilaian Alternatif Kebijakan}

Penilaian alternatif kebijakan adalah tahap akhir dalam membuat rekomendasi kebijakan. Alternatif-alternatif yang telah dibuat akan dibandingkan dan dipilih salah satu menjadi alternatif yang paling layak sebagai solusi untuk mengatasi permasalahan. Penilaian alternatif kebijakan berdasarkan kriteria-kriteria kebijakan yang sudah ditetapkan sebelumnya. Penilaian alternatif kebijakan berguna untuk meramal dan memperhitungkan konsekuensi dari masing-masing alternatif kebijakan. Pada penilaian alternatif-alternatif kebijakan dalam mengatasi perilaku digital di Indonesia menggunakan aspek kriteria kebijakan menurut Bardach (2012), yaitu kelayakan teknis (technical feasibillity), ekonomi dan finansial (economic and financial posibillity), kehidup politik (political viabillity), Pengoprasian Administrasi (administrative Operabillity). Hasil penilaian alternatif kebijakan dalam mengatasi perilaku digital di Indonesia adalah sebagai berikut:

1. Bekerjasama Dengan Perusahaan Media Sosial Dalam Hal Mengawasi Kegiatan Masyarakat di Sektor Digital

Alternatif ini dibuat karena pemerintah Indonesia tidak mampu menjangkau seluruh masyarakat dalam mencegah dan mengawasi kegiatan di sektor digital. 
Bekerjasama langsung dengan perusahaan media sosial diharapkan dapat menjadi perpanjangan tangan pemerintah dalam mengawasi perilaku digital dan mencegah perilaku buruk masyarakat di dunia digital. Penilaian melalui aspek kelayakan teknis, alternatif ini dapat mencapai kriteria mengawasi masyarakat dengan intens dalam menggunakan internet dan sosial media. Penilaian melalui aspek ekonomi dan finansial, alternatif ini cenderung menggunakan dana dan anggaran yang tidak terlalu banyak karena perusahaan media sosial ikut bertanggung jawab untuk mengawasi perilaku digital di Indonesia. Seperti halnya yang terjadi pada negara Australia, Facebook memberikan 1 miliar Dollar AS atau setara dengan 14 trilun rupiah untuk bekerjasama dengan perusahaan media di Australia selama 3 tahun kedepan (Kompas.com, 2021). Penilaian melalui aspek kehidupan politik, alternatif ini cenderung sulit karena bekerjasama dengan perusahaan media sosial berarti memperbanyak stakeholder dan tidak dapat memaksa perusahaan media sosial yang berskala internasional untuk ikut bekerjasama. Penilaian melalui aspek pengoprasian administrasi, alternatif ini akan mendapatkan kendala dalam pengoprasian administrasi dikarenakan banyaknya stakeholder yang terlibat dan juga akuntabilitas yang cenderung tidak jelas.

2. Memberlakukan Persyaratan Khusus seperti Menggunakan E-KTP Atau Identitas Lain untuk Memperoleh Akun di Salah Satu Platform Digital agar Menciptakan "One Person One Account"

Alternatif ini dibuat untuk menciptakan kewaspadaan pengguna internet ataupun sosial media dalam berperilaku karena pemerintah dapat langsung mengetahui identitas asli pemilik akun. Akun palsu (fake account) dapat dibuat dengan mudah sehingga sulit untuk mengetahui identitas asli pengguna akun. Akun palsu sering digunakan beberapa pihak untuk menyebarkan ujaran kebencian kepada orang lain, baik untuk tokoh yang berpengaruh maupun masyarakat biasa (Ayu dan Alfitra, 2019). Alternatif ini bertujuan agar pemilik akun akan lebih bijak dan bertanggungjawab dalam menggunakan internet dan sosial media. Penilaian melalui aspek kelayakan teknis, alternatif ini dapat memenuhi kriteria-kriteria dengan sangat baik. Selain dapat mengawasi perilaku masyarakat di dunia digital, satu orang hanya memilki satu akun akan membuat pengguna takut untuk berperilaku buruk di dunia digital dan akan meningkatkan kesopanan digital Indonesia. Penilaian melalui aspek ekonomi dan finansial, alternatif ini tidak akan menggunakan banyak biaya karena dapat memanfaatkan sistem informasi manajemen yang sebelumnya sudah ada di Indonesia 
seperti E-KTP lalu mensinkronkan dengan platform saat proses pendaftaran akun. EKTP dapat dimanfaatkan untuk mengidentifikasikan pemecahan perkara kejahatan terorisme, pembobolan bank, pemilikan KTP ganda, dan lain-lain, Oktaf (Septiyarini dan Pranaka, 2019). Penilaian melalui aspek kehidupan politik, alternatif ini tentu akan mendapatkan penolakan dari berbagai stakeholder terutama masyarakat karena membatasi kegiatan bersosial media terlebih lagi karena rawan penyalahgunaan data pribadi jika menggunakan E-KTP sebagai syarat memiliki akun. Polri menjelaskan bahwa pemberian foto dan nomor KTP ke pihak lain dapat memberikan celah kepada perilaku tindak pidana untuk melaku melakukan kejahatan (Kompas.com, 2021). Penilaian melalui aspek pengoprasian administrasi, pengelolaan administrasi dalam mewujudkan one person one account tidak akan menjadi masalah besar karena dapat memanfaatkan sistem informasi manajemen yang sebelumnya sudah dikelola oleh negara dengan baik.

3. Mendirikan lembaga khusus untuk perizinan dan pengawasan bagi pengguna dan pihak pengelola Media Sosial

Alternatif ini dibuat untuk mendirikan lembaga baru yang fokus mengawasi pengguna dan pihak pengelola Media Sosial. Seperti halnya pada media massa memiliki pengawasan dalam penyiaran seperti Komisi Penyiaran Indonesia (KPI), Media cetak diawasi oleh Dewan Pers dan media online (website) diawasi oleh Satuan Tugas (Satgas) berdasarkan undang-undang yang dibentuk oleh Dewan Pers. Namun dalam media sosial belum ada lembaga khusus untuk mengawasi aktivitas di media sosial (Khatimah, 2018). Dengan adanya lembaga perizinan tentu akan membuat pengguna dan pihak pengelola media sosial menyetuji ketentuan terlebih dahulu sebelum mengoperasikan kegiatannya di dunia digital. Penilaian melalui aspek kelayakan teknis, alternatif ini dapat dengan leluasa mengawasi perilaku digital masyarakat serta dapat mencegah masyarakat berperilaku buruk karena masyarakat sadar peran negara terjun langsung untuk mengawasi mereka melalui lembaga yang memiliki dasar hukum. Penilaian melalui aspek ekonomi dan finansial, alternatif ini akan menggunakan biaya ataupun anggaran yang sangat besar karena membangun sebuah lembaga baru. Penilaian melalui aspek kehidupan politik, alternatif ini akan mendapatkan berbagai penolakan dari berbagai stakeholder karena akan mempertanyakan fungsi dari lembaga baru ini serta dikhawatirkan fungsi lembaga ini tidak jauh berbeda dengan Kominfo yang sudah ada di Indonesia. Penilaian melalui aspek pengoperasian administrasi, administrasi 
dalam alternatif ini tentu akan lebih optimal karena adanya lembaga khusus yang memang hanya bertugas untuk perizinan dan pengawasan di media sosial.

4. Aktif Melakukan Sosialisasi dan Himbauan Bijak Bersosial Media di Berbagai Platform Media Sosial, Terutama Platform yang Paling Sering Diakses oleh Generasi Z dan Milenial

Alternatif ini dibuat untuk mengajak masyarakat bijak dalam berperilaku saat menggunakan sosial media. Sosialisasi difokuskan kepada generasi Z dan milenial karena generasi tersebut adalah generasi yang paling mendominasi populasi di Indonesia. Menggunakan platform yang paling sering diakses oleh generasi $\mathrm{Z}$ dan milenial meningkatkan kemungkinan sosialisasi tersebut sampai ke mereka. Platform YouTube merupakan yang paling popular di masyarakat Indonesia. 94\% warga Indonesia berusia 16-64 tahun mengakses YouTube (Databoks, 2021). Penilaian melalui aspek kelayakan teknis, alternatif ini tidak dapat secara signifikan mengawasi dan mencegah perilaku buruk di dunia digital karena kecenderungan masyarakat Indonesia yang sering skip iklan menjadi penyampaian informasi tentang bijak bersosial media tidak dapat tersalurkan. Indonesia merupakan negara yang paling banyak blokir iklan daring, 65\% pengguna internet di Indonesia memblokir iklan (Databoks, 2021). Penilaian melalui aspek ekonomi dan finansial, alternatif ini tidak akan menggunakan biaya yang terlalu besar. Penilaian melalui aspek kehidupan politik, alternatif ini tidak akan ada penolakan dari berbagai macam stakeholder karena tidak mengganggu kepentingan orang banyak. Penilaian melalui aspek pengoprasian administrasi, alternatif ini tidak perlu mengkhawatirkan pengoprasian administrasi karena hanya tinggal membuat iklan lalu disalurkan ke berbagai macam platform yang menyediakan jasa penerbitan iklan seperti media massa seperti koran, televisi, radio, dan sebagainya maupun memanfaatkan media sosial.

\section{KESIMPULAN}

Rekomendasi kebijakan setelah dilakukannya penilaian terhadap alternatifalternatif kebijakan adalah menggunakan alternatif kebijakan yang kedua. Alternatif memberlakukan persyaratan khusus seperti menggunakan E-KTP atau identitas lain untuk memperoleh akun di salah satu platform digital agar menciptakan "one person one account" adalah solusi dalam mengatasi perilaku digital di Indonesia. Alternatif ini memiliki banyak kesanggupan dalam memenuhi kriteria-kriteria yang telah ditetapkan. 
Alternatif ini mampu memenuhi kriteria kelayakan teknis, ekonomi/finansial, dan pengoprasian administrasi dengan baik. Aspek kehidupan politik tidak dapat dipenuhi dengan cukup baik karena dikhawatirkan akan adanya penyalahgunaan data pribadi milik pengguna akun. Namun dalam mengatasi hal tersebut, pemerintah Indonesia dapat memberlakukan kode khusus sebelum mendaftarkan akun disalah satu platform. Untuk mendapatkan kode khusus harus menggunakan identitas yang sudah tersinkron dengan sistem informasi manajemen seperti E-KTP atau identitas lain. Media untuk mendapatkan kode tersebut hanya dikelola oleh pemerintah tanpa melibatkan pihak ketiga.

\section{REFERENSI}

Ayu, Ajeng Kartika., \& Alfitra. (2019). Tindak Pidana Ujaran Kebencian Memakai Akun Palsu (Fake Account) di Media Sosial. Journal of Legal Research, 1(1), 126-146.

Bardach, E. (2012). A practical Guide for Policy Analysis - The Eight Fold Guide to more Effective Problem Solving. California: Sage Publications.

BPS. (2020, 15 Desember). Indeks Pembangunan Teknologi dan Informasi 2019. Diakses pada April 2021, dari https://www.bps.go.id/publication/2020/12/15/f52c2f6c113db406967d5cb0/i ndeks-pembangunan-teknologi-informasi-dan-komunikasi-2019-.html.

BPS. (2021, 26 Februari). Statistik Indonesia 2021. Diakses pada 6 April 2021, dari https://www.bps.go.id/publication/2021/02/26/938316574c78772f27e9b477/ statistik-indonesia-2021.html.

Bayu, Dimas Jarot. (2021, 3 Maret). Indonesia Negara yang Paling Banyak Blokir Iklan $\begin{array}{lllll}\text { Daring. } & \text { Diakses } & \text { pada } & \text { April 2021, dari }\end{array}$ https://databoks.katadata.co.id/datapublish/2021/03/03/indonesia-negarayang-paling-banyak-blokir-iklan-daring.

Khairi, H. (2014). Modul 1: Konsep Dasar Kebijakan Publik. Analisis Kebijakan Pendidikan Nasional. Universitas Terbuka.

Khatimah, Husnul. (2018). Posisi dan Peran Media dalam Kehidupan Masyarakat. Tasamuh, 16(1), 119-136.

Kismartini., \& Mualim. (2008). Analisis Kebijakan Penataan Pedagang Kaki Lima (PKL) di Simpang Lima Kabupaten Pati. DIALOGUE: Jurnal Administrasi Publik dan Kebijakan Publik, 5(1), 35-53. 
Lidwina, Andrea. (2021, 7 Februari). 94\% Orang Indonesia Akses Youtube dalam Satu Bulan Terakhir. Diakses pada 6 April 2021, dari https://databoks.katadata.co.id/datapublish/2021/02/17/94-orang-indonesiaakses-youtube-dalam-satu-bulan-terakhir.

Meutia, Intan Fitri. (2017). Analisis Kebijakan Publik. Lampung: CV Anugrah Utama Raharja.

Microsoft. (2021, Februari). Civility, Safety \& Interaction Online: Indonesia. Diakses pada 6 April 2021, dari https://www.microsoft.com/en-us/digital-skills/digitalcivility?activetab=dci reports:primaryr4.

Nataoatmodjo, Soekidjo. (2003). Pendidikan \& Perilaku Kesehatan. Jakarta: Rineka Cipta. Nazir, Moh. (2014). Metode Penelitian. Jakarta: Ghalia Indonesia

Nugroho, Riant. (2009). Public Policy. Jakarta: Alex Media Komputindo.

Pertiwi, Wahyunanda Kusuma. (2021, 25 Februari). Facebook Siapkan Rp 14 Triliun untuk Kerja Sama dengan Media. Diakses 6 Mei 2021, dari https://tekno.kompas.com/read/2021/02/25/20000047/facebook-siapkan-rp14-triliun-untuk-kerja-sama-dengan-media?page=all.

Rusman. (2012). Pembelajaran Berbasis Teknologi Informasi dan Komunikasi. Jakarta: Grafindo.

Septiyarini, Dwi., \& Pranaka, Resky Nanda. Implementasi Program dan Pemanfaatan EKTP yang Terintegrasi di Kabupaten Sambas. Jurnal Administrasi Publik, 7(1), 3042.

Shalihah, Nur Fitriatus. (2021, 12 Maret). Mengapa Tidak Boleh Sembarangan Memberikan Foto dan Nomor KTP. Diakses pada 6 Mei 2021, dari https://www.kompas.com/tren/read/2021/03/12/184300865/mengapa-tidakboleh-sembarangan-memberikan-foto-dan-nomor-ktp-?page=all.

Sugiyono. (2018). Metode Penelitian Bisnis. Bandung: Alfabeta.

_..(2012). Metode Penelitian Kuantitatif Kualitatif dan R\&B. Bandung: Alfabeta.

Suharto, Edi. (2005). Membangun Masyarakat Memberdayakan Rakyat. Bandung: Refika Aditama.

Sutrisno. (2011). Pengantar Pembelajaran Inovatif Berbasis Teknologi dan Komunikasi. Jakarta: Gaung Persada.

Vernanda, Rengga. (2019). Kesiapan Indonesia Menuju Agile Governance. Konferensi Nasional Ilmu Administrasi, 1-6. 